\title{
Close of Play for the Select Commitiee
}

MR John DAvies, Secretary of State for Trade and Industry, last week failed to raise the hopes of the Select Committee on Science and Technology that the government would appoint a Minister for Research and Development. Appearing before the committee at the last public meeting of its enquiry into the state of government research and development, Mr Davies said that he could not see the advantages of having such a minister. The select committee recommended in a recent report that such a minister be appointed (see Nature, 237, 63; 1972).

Mr Davies's distinctly cool attitude towards the proposal arises because most research and development carried out by government departments is tied up with specific projects, and is not a case of research for the sake of research. This kind of research would remain in the care of the departments even if a minister were appointed, said $\mathrm{Mr}$ Davies, and in these circumstances a Minister for Research and Development would face difficulties because "vast areas of research and development would not be in his control".

Mr Davics was similarly sceptical of the select committee's recommendation that government research and development should be formulated on a five year rolling basis. If such a plan were instituted, said Mr Davies, it must have a "substantial contingency element" because "so much of the DTI's research and development programme arises from meetings and projects". But $\mathrm{Mr}$ Davies did point out that some 10 per cent of the DTI's research and development could be formulated on a five year basis and therefore could be put under the aegis of a Minister for Research and Development.

Mr Davies said that there would be "substantial changes" in collaborative ventures with Europe once Britain joins the European Communities. He considers that the industries which would benefit most would be those involved in nuclear systems and aerospace ; computer technology would reap the advantages eventually but on a longer time scale.

No predictions were made by the secretary of state about Britain's future policy towards ELDO. In fact no decision on Britain's future aerospace commitments will be made, according to $\mathrm{Mr}$ Davies, until the present British study of the post-Apollo programme is completed in the autumn of this year.

In spite of $\mathrm{Mr}$ Davies's enthusiasm for collaborative research and develop- ment programmes within Europe, a note of reserve was evident when he said that it is not easy to get such European cooperative programmes off the ground. Mr Davies did, however, say that he thought changes would occur much more rapidly once Britain is in the EEC.

Earlier last week $\mathrm{Mr}$ Michael Heseltine, Minister for Aerospace, also gave evidence to the select committee. Under considerable pressure from the members of the committee he outlined the possible areas of research and development to be covered by the requirements boards which the Department of Trade and Industry plans to introduce this autumn. He emphasized that these are only his first thoughts and that they may well change.

The boards, coming in the wake of Lord Rothschild's customer-contractor principle, are intended to act as customers within DTI spending about $£ 25$

\section{GRADUATE EMPLOYMENT}

\section{Plugging them in}

A COMPUTER placement service to help graduates find jobs is to come into operation in a trial form this October. The service, known as CAP (Computer Assisted Placement), will be available at sixteen universities and colleges this autumn and more than 100 employers plan to take part.

The scheme is to be run by a nonprofit making company set up by the Standing Conference of Employers of Graduates (SCOEG) whose 200 member companies include many of the large graduate employers-Shell and Metal Box for example. The service will be free to students, finance coming from the participating companies.

The scheme, which was discussed in detail by the Standing Conference of University Appointments Services (SCUAS) last autumn (see Nature 233, $84 ; 1972$ ), is intended to provide better information to both employers and prospective graduate employees about what jobs and which people are available. Every student will get a list of the 20 most likely jobs from the computer and every employer will get a list of up to 50 potential recruits.

The scheme is not dissimilar to a computer placing system that has been operating in the United States for some years, and details of which were given to appointments officers at SCUAS's meeting last September. It is claimed that the system should encourage com. million of the $£ 200$ million that is the DTI's civil research budget. The boards will buy the research the department feels it needs from either its own research establishments, the non-nuclear arm of the Atomic Energy Authority, industry or the universities. In time the boards will also handle the knotty problem of the industrial research associations.

$\mathrm{Mr}$ Heseltine said that he envisages between six and ten boards covering the areas of standards and metrology, marine and maritime technology, mechanical engineering and machine tools, materials, chemical and mineral processes and plant, computers and electronics ; there may also be a board to deal with miscellaneous matters. $\mathrm{Mr}$ Heseltine also said that he is contemplating boards for waste and effluent technology, safety and health, and for the laboratory of the government chemist.

panies who have not employed graduates before to do so and should help the student to clarify his or her ideas. It is not intended, however, that CAP will replace any part of the university appointments procedure as it now exists, it is intended simply to augment it.

The operation starts with the employer who describes the job he has to offer under seven separate headings; a job profile is produced from this at the Bootle computer centre of the Post Office National Data Processing Service and a list of profiles is sent to the appointments boards. Students consult the list and fill in forms containing the same seven headings as the employers used and these are matched by the computer against the jobs. Employers and students each receive the results and the employer may then contact applicants through the appointments boards.

It is claimed that the scheme-which has the blessing of appointments boards, the National Union of Students and employers alike-is completely confidential. Students names will not be disclosed to employers without the student's permission and use of the scheme implies no obligation on the part of students.

Included among the employers taking part are the Civil Service Commission, the armed forces, nationalized industries and private companies: the customers to start with will include the Universities of Oxford, Manchester, Kent, Sussex and Wales and Lancaster Polytechnic as well. 